ks. Edward Staniek

\title{
Kazania okolicznościowe św. Jana Złotoustego
}

Kazanie okolicznościowe to przekaz słowa Bożego, w którym kaznodzieja potrafi wykorzystać wydarzenie, a zwłaszcza związane z nim nastroje słuchaczy. Dokonuje tego albo jak skoczek narciarski, korzystając ze sprzyjającego podmuchu wiatru i - wśród oklasków kibiców - bijąc rekord skoczni, albo jak dobry bokser, mocną kontrą nokautując przeciwnika, albo jak przywódca tłumu ukierunkowujący jego energię do twórczego działania.

Ważnym elementem okolicznościowego kazania jest umiejętność potraktowania danego wydarzenia jako znaku czasu i ukazania obecnej w nim ewangelicznej wartości.

Kolejnym warunkiem kazania sytuacyjnego jest zdolność kaznodziei do syntezy, która polega na wskazaniu możliwie najkrótszej drogi, jaka wiedzie od wydarzenia do tego, co najważniejsze i ponadczasowe. Jest to sztuka przejścia od fenomenu do egzystencjalnej głębi.

Mam ukazać Jana Chryzostoma jako mistrza kazań okolicznościowych, a nie jestem w stanie dokładnie podać, ile takich mów wygłosił, ani nawet wskazać, ile się ich zachowało. Upłynie jeszcze sporo czasu, zanim uda się krytycznie opracować dorobek Jana, by ustalić autentyczność jego kazań, udowodnić, które z nich są przez niego autoryzowane, a które pozostają tylko zapisem słuchaczy. W tej sytuacji moje słowo ograniczę do kilku luźnych refleksji. Nie będzie to więc ani systematyzacja całości interesującego nas materiału, ani tym bardziej próba jego syntetycznego ujęcia.

Wspomnę, że zachowało się jego pierwsze kazanie prymicyjne. Widać w nim nowicjusza na ambonie, który nie ma nawet odwagi dedykować swego kazania Bogu na chwałę, z racji niedoskonałości swego słowa. Jan sprytnie uciekł od tematu swego kapłaństwa i przeszedł w panegiryk na cześć biskupa, który udzielił mu święceń.

W pewnej mierze do kazań okolicznościowych należy zaliczyć osiem jego mów zatytułowanych Przeciw Żydom. Jan głosił je najczęściej w przeddzień świąt żydowskich, licząc się z ich kalendarzem liturgicznym. W kazaniach stara się wyciszyć zbyt mocny entuzjazm sympatii wielu chrześcijan Antiochii do synagogi żydowskiej. Przejawiał się on w tłumnym uczestniczeniu 
ochrzczonych, nie zawsze tylko w formie gapiów, w obrzędach żydowskich. Dziś po studium Jana Iluka ${ }^{1}$ możemy powiedzieć, że tytuł ogólny tego cyklu nie odpowiada w pełni treści wygłoszonych kazań. Jan nie tyle atakuje Żydów, ile chrześcijan o nastawieniu prożydowskim.

Już w drugim roku po święceniach Jan miał okazję udowodnić, że jest kaznodzieją okolicznościowym dużej klasy. Zadecydowała o tym sytuacja. Obywatele Antiochii ulegli prawdopodobnie sterowanej propagandzie i wzniecili rozruchy przeciw rozporządzeniu cesarza, który zwiększył podatki. W czasie rozruchów doszło do zniszczenia portretów władcy umieszczonych w formie płaskorzeźb w miejscach publicznych. Czyn ten z punktu widzenia prawa został potraktowany jako obraza cesarskiego majestatu.

Emocje opadły. Wszyscy uświadomili sobie, że nic przez to dla siebie nie zyskali, a konsekwencje ich czynu dla stolicy metropolii mogą być bardzo przykre. Znali bowiem cesarza Teodozjusza, który działając w gniewie bywał nieobliczalny.

Aresztowano radców miasta i wydano na nich wyroki. Zamknięto teatr, cyrk, warsztaty pracy... Miasto czekało na ostateczne decyzje cesarza. Pod wyrokami śmierci miał bowiem złożyć on swój podpis. Atmosfera w mieście była ciężka i przypominała stan wyjątkowy. Jedni z miasta uciekli, inni nie wychodzili na ulice, a jeszcze inni tłoczyli się w kościele, szukając nadziei.

Posiadamy dwie dość dokładne relacje tych wydarzeń ${ }^{2}$. Jedna z nich pochodzi od Libaniusza, mistrza Jana Chryzostoma, który siedział po stronie trybunału sędziów strzegących sprawnego funkcjonowania machiny administracyjnej. Jego pięć Mów powstało najprawdopodobniej już po zakończeniu konfliktu. Wiele wskazuje na to, że nie były one głoszone, lecz jedynie przeznaczone do czytania.

Druga relacja jest zawarta w Mowach Jana, które były głoszone i ilustrują na bieżąco rozwój wydarzeń. Chryzostom wprawdzie z racji wielkiego postu trzymał się tekstów Pisma Świętego przypadających na ten okres, ale wyjaśniał je ludziom podszytym strachem o swe jutro i o los miasta. Biskup Flawian razem z delegacją wyjechał do Konstantynopola, by prosić władcę o ułaskawienie. Upływały tygodnie. Jan czekał na wieść od swego ordynariusza. Cesarz przebaczył miastu. Jan mógł wkomponować tę wiadomość w radosną pieśń o zwycięstwie Chrystusa zmartwychwstałego nad światem i nad grzechem. Cykl kazań O pomnikach lub O posagach, bo pod taką

${ }^{1}$ J. Iluk, Żydowska politeja i Kościół w imperium rzymskim u schyłku antyku, t. 1: Jana Chryzostoma kapłana Antiochii Mowy przeciwko Judaizantom i Żydom, Gdańsk 2006.

${ }^{2}$ Dokładniejsze omówienie atmosfery, w jakiej Jan głosił kazania o posągach podaje J. N. D. Kelly, Złote usta. Jan Chryzostom, Bydgoszcz 2001, s. 81-91. 
nazwą przeszły one do historii, jest przykładem nie tylko dobrego kaznodziejstwa okolicznościowego, lecz i politycznego. Jan akcentuje w nich rolę, jaką w pojednaniu z władcą odegrał biskup Flawian, a więc Kościół.

Chryzostom liczył wówczas trzydzieści siedem lat, a sława jego kaznodziejskiego talentu, który umie wykorzystać nastroje słuchaczy, rozchodziła się daleko poza granicami Antiochii. Trzeba dodać, że kazania te są twardym rachunkiem sumienia ówczesnych chrześcijan. Można też w nich dostrzec pełną miłości troskę o pogan, których lęk o jutro zapędził pod ambonę Jana.

Należy zauważyć, że Chryzostom, który w 387 roku w Antiochii dobrze rozegrał trudną partię po obaleniu posągów cesarskich, siedemnaście lat później w Konstantynopolu potknął się o posag cesarzowej Eudoksji. Tego kazania z racji politycznych stenografowie nie zanotowali, ale pewne wypowiedzi Jana powtarzano dosłownie i zostały przekazane potomnym. Jan otoczony nie tylko entuzjazmem tłumu, ale wprost uwielbieniem stał się zagrożeniem dla panujących. Znaczny udział w państwowych decyzjach miała wówczas małżonka cesarza Eudoksja. Chcąc ratować swój autorytet, zgodziła się na ustawienie jej posągu i uroczyste jego odsłonięcie połączone z suto zastawionym stołem dla mieszkańców stolicy. Pomysł ustawienia tego posągu między pałacem cesarskim a katedrą Jan skrytykował, a to zostało wykorzystane przeciw niemu.

Brak autoryzowanego tekstu przemówienia nie pozwala w pełni ocenić kaznodziejskiego kunsztu Jana ani ukazać, jaką prawdę Ewangelii przy tej okazji chciał przybliżyć słuchaczom. Przekazano jedynie fragmenty jego przemówienia. Do nich należy słynna wypowiedź biskupa stolicy po odczytaniu perykopy Ewangelii o ścięciu Jana Chrzciciela. Miał wówczas powiedzieć: „Herodiada znowu szaleje i żąda głowy Jana”. Trudno dziś rozstrzygnąć, w jakiej mierze jest to wyrwany z kontekstu cytat Jana, a w jakiej manipulacja jego wrogów, których zawsze miał wokół siebie sporo. Aluzja do cesarzowej przez wymienienie imienia Herodiady była jednak zbyt mocna. Jan pełen goryczy prawdopodobnie nie wyważył słów jak trzeba. Zapłacił za to wysoką cenę zesłania i śmierci. Porównanie pod tym względem finału życia Jana Chrzciciela z finałem życia świętego biskupa stolicy narzuca się samo. Dystans, jaki wobec Chryzostoma po tym jego przemówieniu zastosowali duchowni stolicy, świadczy, że i oni uznali, iż w tej konfrontacji ich ordynariusz przesadził. Większość z nich go opuściła.

W refleksji nad kazaniami okolicznościowymi pragnę zatrzymać się nieco dłużej nad mową, jaką wygłosił Jan w stolicy, a więc jako biskup, po upadku Eutropiusza ${ }^{3}$. Był to minister finansów słynący z korupcji

${ }^{3}$ Tekst kazania w E. Staniek, Wielcy kaznodzieje Kościoła starożytnego. Antologia, Kraków 2007, s. 498-502. 
i wielu nadużyć. W zdobywaniu pieniędzy bezkarnie łamał prawo na oczach wszystkich. Czara nieprawości się jednak wypełniła i wydano na niego wyrok śmierci. On jednak, korzystając z prawa azylu, uciekł do katedry i uchwycił się ołtarza. Pogańskie prawo nadal szanowało przywilej azylu, czyli schronienia się w świątyni.

Prawdopodobnie ta ucieczka miała miejsce wieczorem. W katedrze otoczonej służbą bezpieczeństwa zgromadziły się tłumy, czekając na finał tego wydarzenia. Wszyscy wyrażali wściekłość na Eutropiusza i żądali wydania go w ręce sprawiedliwości. Jan miał do dyspozycji noc, by przygotować mowę, jak na niego zwięzłą, ale świadczącą o jego genialnych zdolnościach kaznodziejskich.

Rozpoczął kazanie od słów Koheleta: „Marność nad marnościami i wszystko marność”. Co kilka zdań wbijał te słowa w głowy słuchaczy jak refren, ukazując minioną wielkość Eutropiusza i tragedię jego klęski.

Fortuna się obróciła przeciwko temu, który był otoczony setkami służalców, wazeliniarzy. Ten, którego wszyscy się bali, siedział teraz na stopniach ołtarza blady jak trup, szczekając ze strachu zębami. Jan miał przed sobą żywy eksponat. Mówi o nim, ukazując go jako przykład człowieka, który fatalnie obrał drogę swego życia. Zwraca się do niego: „Czyż nie upominałem cię? Dlaczego słuchałeś pochlebców, a nie mnie?”. Głośny dialog retoryczny musiał robić na słuchaczach wielkie wrażenie, tym bardziej że znali Eutropiusza i znali Jana. Wiedzieli, że Złotousty mówi prawdę. Widzieli, jak kończy się droga, którą wędrował najbogatszy człowiek w cesarstwie.

Celem kazania było jednak wezwanie do przebaczenia. Takie bowiem jest ewangeliczne rozwiązanie wszystkich podobnych sytuacji. Jan miał przed sobą tłum dyszący nienawiścią i zemstą. Ten tłum najchętniej by zlinczował byłego ministra. Mówca postanowił nie tylko ostudzić te mało ludzkie uczucia nienawiści i zemsty, postanowił on wezwać uczestników wydarzenia - wielu skrzywdzonych przez Eutropiusza - do tego, aby mu przebaczyli. Chciał również, aby wsparli jego prośbę skierowaną do cesarza o ułaskawienie winnego ${ }^{4}$.

Jan nie uczynił tego wprost, bo wiedział, że nie wolno przeciwstawić się nastrojom tłumu. Uczynił to, śpiewając pieśń pochwalną na cześć Kościoła, Matki, która zawsze przebacza. Ta pieśń jest tak piękna, że kaznodzieja mógł w ostatnich jej wersetach umieścić słowa o potrzebie przebaczenia w sercu swemu winowajcy.

Gdybym miał piękną dykcję, świetną pamięć i duże zdolności aktorskie, to - w ramach podjętego tematu - wygłosiłbym to jedno kazanie Jana Chry-

${ }^{4}$ Janowi udało się uzyskać ułaskawienie dla Eutropiusza, tak że nie wykonano wyroku. W krótkim jednak czasie po tym wydarzeniu został on ponownie osądzony i wyrok wykonano. 
zostoma i wszyscy czcigodni zgromadzeni na tej sali zrozumieliby, czym jest kazanie okolicznościowe. Obok danych aktorskich, które Jan posiadał w stopniu wyjątkowo wielkim, brakuje mi jeszcze tego, co było mocą tego kaznodziei, jego świętości. Słuchacze doskonale wiedzieli, że słowa Jana płyną z serca, które umie przebaczać. Jeśli nawet wówczas, pod amboną, nikogo nie było stać na przebaczenie, wszyscy wiedzieli, że Jan już dawno przebaczył Eutropiuszowi krzywdy wyrządzone przez niego Kościołowi.

Do wspomnianych na początku trzech warunków dobrego kazania okolicznościowego należy więc dodać jeszcze jeden, a jest nim autentyzm ewangelicznego życia tego, kto takie kazanie głosi. Dźwięk jego świadectwa decyduje o mocy słów, które wypowiada.

Kazania okolicznościowe należą do najtrudniejszych. Wymagają bowiem bardzo dobrej znajomości prawdy objawionej, świetnej orientacji w sytuacji oraz mocy potrzebnej do panowania nad reakcją tłumów. Jan posiadał te karty atutowe i dlatego zostanie jednym z niedościgłych mistrzów przemówień okolicznościowych. W opracowaniu dorobku kaznodziejskiego Złotoustego mówcy trzeba będzie poddać dokładnej analizie wszystkie jego kazania tego typu. Jest to nie tylko cenne studium z zakresu historii kaznodziejstwa, lecz także bardzo aktualna lekcja potrzebna wszystkim, którzy dziś przemawiają publicznie. W dobie mediów opanowanie tego typu przemówień jest szczególnie ważne.

Kraków

KS. EDWARD STANIEK

\section{Słowa kluczowe}

Jan Chryzostom, homilia, kazanie okolicznościowe, synteza, znak czasu, świadectwo

\section{Summary}

\section{Occasional sermons of St. John Chrysostom}

Occasional sermons belong to the most difficult sermons as they require good knowledge of the revealed truth, preaching talent, the ability to think in the category of synthesis and a strong personality of the preacher. In the sermons Against the Jew, On the Statutes, and After the fall of Eutropius John Chrysostom has proved that he has mastered the art of occasional sermons in a perfect way.

\section{Key words}

John Chrysostom, homily, occasional sermon, synthesis, sign of temps, testimony 
